\title{
Pendidikan Gender: Kedudukan Ikhwan dan Akhwat Perspektif Hadis Shahih
}

\author{
Wisudatul Ummi Tanjung \\ *Pascasarjana UIN SUKA Riau
}

Keywords:

Pendidikan Gender, Ikhwan dan Akhwat, Hadis Shahih

*Correspondence Address: wisudatulummi2380@gmail.co $\underline{\mathrm{m}}$

\begin{abstract}
Discussions relating to women are very important to be studied, so that there is no mistake in placing women's positions. This study aims to describe the equality between men and women. This type of study is library research by collecting secondary data and analyzed descriptively. The results of this study indicate that it is very important to understand and explore the meaning implied in the hadith, because otherwise a distorted understanding will arise.
\end{abstract}

Abstrak: Pembahasan yang berkaitan dengan perempuan sangat penting untuk dikaji, agar tidak salah dalam menempatkan kedudukan perempuan. Kajian ini bertujuan untuk mendeskripsikan kesetaraan laki-laki dan perempuan. Jenis kajian ini adalah penelitian pustaka dengan mengumpulkan data sekunder serta dianalisis secara deskriptif. Hasil kajian ini menunjukkan bahwa sangat penting memahami dan mendalami makna yang tersirat di dalam hadis, karena jika tidak maka akan timbul pemahaman yang menyimpang.

\section{PENDAHULUAN}

Pendidikan merupakan hal penting dalam meningkatkan kualitas kehidupan seseorang. Dengan adanya pendidikan, manusia dapat mengembangkan dirinya dalam mengetahui banyak hal. Terutama hal yang berkaitan dengan kajian gender, karena masih banyak masyarakat yang salah paham dalam mengartikan gender.

Dalam masyarakat istilah gender selalu dikaitkan dengan perempuan. Seakan-akan gender itu hanya berkaitan dengan perempuan saja. Pandangan seperti ini sungguh keliru dalam memahami makna gender. Karena antara laki-laki dan perempuan sama kedudukannya.
Pendidikan agama Islam merupakan sarana yang harus diberikan guna untuk memahamkan kebenaran tentang kedudukan serta hak perempuan. Hal ini dilakukan agar tidak terjadi bias gender dalam memahami makna laki-laki dan perempuan. ${ }^{1}$

Dalam hukum Islam sering membahas tentang gender, dalam kajian tersebut terjadi perbincangan dan perdebatan mengenai status, peranan, serta kesetaraan antara lakilaki dan perempuan. ${ }^{2}$

Sebenarnya hal tersebut sudah dijelaskan melalui firman Allah yang

\footnotetext{
${ }^{1}$ Yassirli Amria Wilda, 2018, hlm. 7

2Supardin, Kajian Gender Perspektif Hadis Nabi, Jurnal: Al-Fikr. Vol. 12 (1), 2013, hlm. 49
} 
menjelaskan kedudukan antara lakilaki dan perempuan. Dalam al-qur'an juga sudah dijelaskan bahwa laki-laki dan perempuan adalah setara, pembeda diantaranya hanya terletak pada ketaqwaannya saja. Hal tersebut juga sudah ada dalam Q.S Al-Hujuraat [49]13 yang berbunyi:

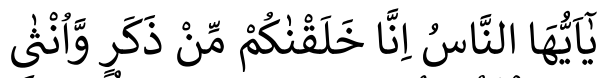

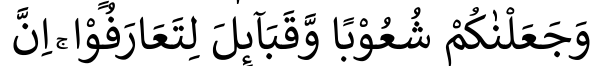

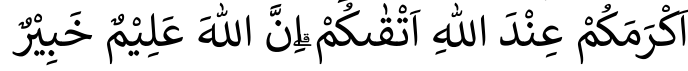

Kajian yang berkaitan dengan gender sudah ada dilakukan oleh penulis terdahulu. Namun, walaupun sudah ada kajian terdahuluu tetap saja masih ada kesalahan dalam memaknai kedudukan laki-laki dan perempuan.

Hal tersebut juga yang terjadi di lingkungan sekitar penulis, di mana laki-laki itu lebih diandalkan dalam segala hal, sehingga perempuan tidak terlalu banyak gerak. Contohnya pemilihan ketua kelas, laki-laki menjadi prioritas, tanpa memberikan kesempatan kepada perempuan.

Selain itu banyak juga masyarakat dari kaum laki-laki yang menganggap remeh tentang kemampuan seorang perempuan, mereka sudah menilai rendah sebelum perempuan tersebut melakukannya.

Hal senada dengan penelitian yang dilakukan oleh Fadlan yang menjelaskan perempuan dianggap sebagai makhluk yang kurang berpengetahuan sehingga selalu berada dalam bimbingan laki-laki. ${ }^{3}$

Berdasarkan persoalan di atas, maka masih banyak hadis hadis yang menarik dikaji terutama terkait

3 Nur Kholifah Dan Dede Mercy Rolando, Stereotipe Perempuan Dakwah Ustadz Abdul Somad: Perspektif Representasi, Al-Idza'ah: Jurnal Dakwah Dan Komunikasi, Vol. 2 (2), 2020, hlm. 47. dengan perempuan. Dengan demikian, kajian ini berusaha menjelaskan secara detail terkait dengan kedudukan antara ikhwan dan akhwat yang sama dihadapan Allah.

\section{METODE}

Kajian ini merupakan sebuah karya tulis yang membahas seputar fikih. Jenis kajian ini adalah kepustakaan (libraryresearch) yaitu mendalami buku dan kitab hadis yang berkaitan dengan kedudukan antara laki-laki dengan perempuan.

Analisis yang digunakan dalam kajian ini adalah deskriptif. Dengan analisis ini penulis akan melakukan kajian historis terkait dengan hadis yang berkaitan dengan kedudukan ikhwan dan akhwat. Sedangkan sumber data yang digunakan dalam kajian ini adalah data sekunder yang diperoleh secara tidak langsung dari sumbernya, seperti dokumendokumen yang berkaitan dengan fokus kajian. ${ }^{4}$

Jadi untuk sumber data dari kajian ini adalah kitab hadis yang berkaitan dengan kedudukan antara ikhwan dan akhwat.

\section{HASIL DAN PEMBAHASAN \\ Karakter Ruang Lingkup Gender}

Ada banyak sekali para tokoh yang telah menjelaskan tentang pengertian gender. Diantaranya Umar yang menjelaskan bahwa kata gender berasal dari bahasa inggris, yaitu gender yang memiliki makna jenis kelamin. Dalam Webster's New World Dictionary gender diartikan sebagai perbedaan yang tampak antara laki-

\footnotetext{
${ }^{4}$ Amri Darwis, Metode Penelitian Pendidikan Agama Islam Pengembangkan Ilmu Beroaradigma Islami, (Pekanbaru:Suska Press, 2021), hlm. 120).
} 
laki dan perempuan dilihat dari segi nilai dan tingkah laku. ${ }^{5}$

Perbedaan gender pada prinsipnya adalah hal wajar dan sebagai sebuah fenomena dalam kebudayaan. Perbedaan tidak akan menjadi masalah jika tidak timbul ketidakadilan. Namun pada kenyataannya perbedaan tersebut menjadi ketidakadilan baik bagi lakilaki terutama kepada perempuan. ${ }^{6}$

Masyarakat di luar sana banyak yang belum memahami betul apa itu gender. Mereka hanya beranggapan kalau gender itu hanya sekedar jenis kelamin saja, tetapi lebih jelas bahwa gender itu adalah suatu konstruksi budaya tentang peran fungsi dan tanggung jawab sosial antaralaki-laki danperempuan. Kondisi demikian mengakibatkan kesenjangan peransosial dan tanggung jawab sehingga terjadi diskriminasi, terhadap laki-laki danperempuan. ${ }^{7}$

Jadi dapat disimpulkan bahwa gender adalah perbedaan yang tampak pada laki-laki dan perempuan apabila dilihat dari nilai dan tingkah lakunya. Gender merupakan suatu istilah yang digunakan untuk menggambarkan perbedaan antara laki-laki dan perempuan secara sosial. Gender adalah kelompok atribut dan perilaku secara kultural yang ada pada laki-laki dan perempuan. ${ }^{8}$

Banyak kesalahan dalam mengartikan istilah sex dan gender. Keduanya memang memiliki persamaan dan perbedaan. Agar lebih jelas perlu diketahui terlebih dahulu

${ }^{5}$ Nassaruddin Umar, Ibid,hlm 29.

6Ridwan, Kekerasan Berbasis Gender, (Yogyakarta: Fajar Pustaka, 2006), hlm. 25

${ }^{7}$ Iswah Adriana, Kurikulum Berbasis Gender. Jurnal Tadris. Vol.4 (1). 2009, hlm. 140

${ }^{8}$ Dwi Narwoko dan Bagong Yuryanto, Sosiologi Teks Pengantar dan Terapan, (Jakarta:Kencana Prenada Media Group, 2004), hlm. 334 persamaandan perbedaan sex dan gender tersebut. Sex dan gender memiliki arti yang sama yaitu jenis kelamin, akan tetapi masing-masing keduanya memiliki konsep yang berbeda-beda.

Menurut Mansour Fakih sex lebih condong pada jenis kelamin manusia berdasarkan ciri biologis yang melekat, tidak dapat dipertukarkan serta berubah karena merupakan ketentuan dari Tuhan (kodrat). Sedangkan konsep gender adalah sifat yang melekat pada laki-laki atau perempuan yang muncul melalui sosial atau budaya yang dapat dipertukarkan dan bisa berubah dengan sesuai perkembangan zaman. Jadi gender diartikan sebagai jenis kelamin sosial, sedangkan sex adalah jenis kelamin biologis. $^{9}$

\section{Hadis-Hadis Gender.}

Dalam bahasa Arab tidak ditemukan kata yang sama dengan kata gender, namun terdapat kata aldzakar dan al-untsa serta kata ar-rijal dan an-nisa yang biasa digunakan merujuk pada laki-laki dan perempuan. Al-dzakar digunakan untuk menyatakan laki-laki dilihat dari faktor biologis. Al-untsa berarti lemas, lembut, halus, lafadz ini menunjukkan jenis perempuan dari aspek biologisnya. Ar-rijal artinya lakilaki yang umumnya digunakan untuk laki-laki yang sudah dewasa. An-nisa adalah bentuk jamak dari mar'ah yang berarti perempuan, umumnya digunakan untuk perempuan yang sudah dewasa, berkeluarga, janda, bukan perempuan dibawah umur. Dengan begitu ar-rijal dan an-nisa

\footnotetext{
${ }^{9}$ Mansour Faqih, Analisis Gender dan Transformasi Sosial, (Yogyakarta: Pustaka Pelajar, 2006), hlm. 8
} 
berkonotasi laki-laki dan perempuan dalam relasi gender. ${ }^{10}$

Ada banyak sekali hadis-hadis yang mengkaji tentang gender ini. Namun di sini penulis hanya menjelaskan beberapa hadissaja yang digunakanterkait mengkaji dalam isu gender, akan tetapi perlu pengkajian lebih dalam lagi agar sesuai dengan seiring perkembangan zaman. Di antara hadis-hadis yang sering digunakan dalam dalil kesetaraan gender yaitu sebagai berikut ini:

1. Tanggung Jawab Suami dan Istri dalam Rumah Tangga.

\section{Sanad dan Matan}

Menurut Al-Qur'an, perempuan adalah syaqaiq arrijal (saudara sekandung kaum laki-laki), sehingga kedudukan serta hak-hak keduanya hampir sama, perbedaan hanyalah tentang fungsi serta tugas utama yang dibebankan Tuhan kepada masing-masing. Perbedaan tersebut tidaklah mengakibatkan pada kelebihan dari orang lain. Mengenai tugas dan tanggung jawab suami istri dalam keluarga merupakan persoalan yang lumayan rumit dipahami. Adapun hadis yang membahas permasalahan ini terdapat pada Shahih al-Bukhari dalam kitab nikah, yaitu:

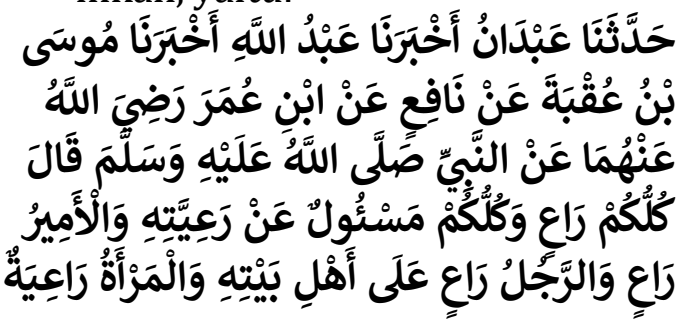

\footnotetext{
${ }^{10}$ Mayola Andika, Reinterpretasi Ayat Gender Dalam Memahami Relasi Laki-Laki dan Perempuan, Jurnal: Musawa. Vol. 17 (2), 2018, hlm. 140.
}

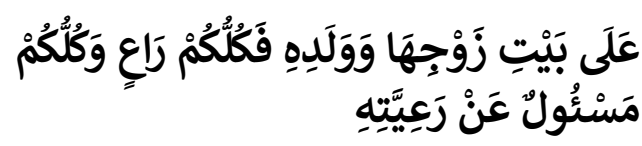

Terjemah:

"Telah menceritakan kepada kami Abdan Telah mengabarkan kepada kami Abdullah Telah mengabarkan kepada kami Musa bin Uqbah dari Nafi' dari Ibnu Umar radliallahu 'anhuma, dari Nabi Shallallahu 'Alaihi Wasallam, beliau bersabda: "Setiap kalian adalah pemimpin. Dansetiap kalian akan dimintai pertanggungjawaban terhadap yang dipimpinnya. Seorang Amir adalah pemimpin. Seorang suami juga pemimpin atas keluarganya. Seorang wanita juga pemimpin atas rumah suaminya dan anakanaknya. Maka setiap kalian adalah pemimpin dan setiap kalian akan dimintai pertanggungjawaban atas yang dipimpinnya." (HR. Bukhari No. 4801).

\section{Penjelasan}

Dari hadis di atas dapat dipahami peran dan tanggung jawab suami istri adalah senantiasa seimbang dengan fitrah perempuan dan laki-laki sebagai hamba Allah Swt. Keduanya telah diatur berdasarkan tugas dan kemampuannya masing-masing. Hadits di atas mengandung makna bahwa seorang laki-laki dan perempuan adalah pemimpin. Seorang suami adalah memberikan perlindungan dan memenuhi nafkah kebutuhan anggota keluarga berkaitan dengan kebutuhan makan, minum, pakaian, dan tempat tinggal (rumah), selain itu memperlakukan anggota keluarga dengan sebaik-baiknya. 
Sedangkan yang terkait dengan kepemimpinan istri adalah yang berkaitan dengan mengatur dengan baik urusan rumah tangga, mendidik anak dengan sebaik-baiknya, dan memberikan nasihat kepada suami. Adapun terkait dengan pembantu dia harus berupaya menjaga harta benda tuannya dan melaksanakan tugasnya dengan sebaik-baiknya. Mereka semua memiliki tanggung jawab dibidang dan tugas masingmasing. ${ }^{11}$

Dari penjelasan di atas dapat kita ketahui bahwa tidak ada seorang pun yang luput dari tanggung jawab, mulai dari orang yang mempunyai kedudukan tertinggi sampai kepada hamba sahaya. Minimal seseorang tersebut mampu bertanggung jawab terhadap kemaslahatan dirinya sendiri. Dan semua orang harus melaksanakan tugasnya dengan sebaik-baiknya dengan berlaku adil terhadap obyek yang menjadi diembanya, berusaha mewujudkan kemaslahatan tersebut.

Pada dasarnya orang yang diungkapkan dalam hadis ini bukanlah untuk membatasi. Tidak ada orang yang lepas dari tanggung jawab, karena kalimat "Kalian semua adalah pemimpin" mencakup semua orang tanpa kecuali. Tetapi ini hanyalah sekedar contoh, yang intinya semua orang harus memahami bahwa mereka tidak diciptakan hanya sia-sia, namun masingmasing dibebani tanggung jawab

11 Muhammad al-Husain al-Baqwiy. Syarah AlSunnah. (Beitur 1992) hlm. 311-312. yang harus dipertanggung jawabkan.

\section{Kewajibandan Hak Antara Suami Istri.}

\section{Sanad dan Matan}

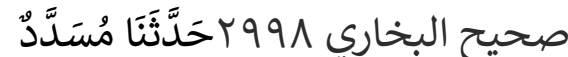

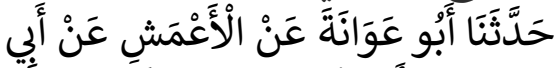

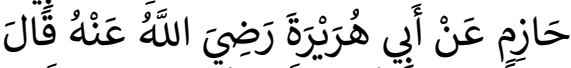

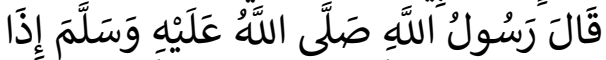

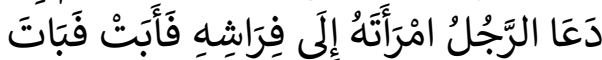

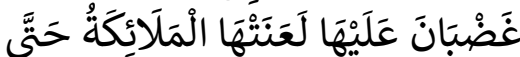

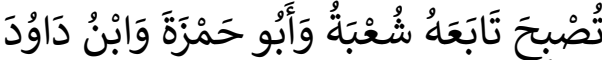

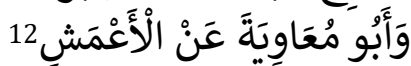

Terjemah:

Shahih Bukhari 2998: Telah bercerita kepada kami Musaddad telah bercerita kepada kami Abu 'Awanah dari Al A'masydari Abu Hazim dari Abu Hurairah radliyallahu 'anhu berkata: Rasulullah shallallahu 'alaihi wasallam bersabda: "Jika seorang suami mengajak istrinya ke tempat tidurnya, lalu istrinya menolaknya sehigga dia melalui malam itu dalam keadaan marah, maka malaikat melaknat istrinya itu hingga shubuh." Haditsini diikuti pula oleh Syu'bah, Abu Hamzah, Ibnu Daud dan Abu Mu'awiyah dari Al A'masy.

\section{Pendapat Ulama}

Yusuf al-Qaradhawi mewajibkan istri untuk memenuhi panggilan suami ketika suami memintanya untuk tidur seranjang dengannya, jugamelarang menyelisihinya

${ }^{12}$ Op. Cit., PDF Sohih Bukhari, Hal. 1418-1419 
dalam suatu perkara. Terkait dengan kewajiban seorang istri untuk memenuhi ajakan suami, Yusuf al-Qaradawi tidak mewajibkan secara mutlak. Kewajiban melayani tersebut hendaknya segera dipenuhi, jika istri tidak sedang dalam keadaan udzur yang dibenarkan oleh syariat. Sebagaimana penjelasan Yusuf al-Qardhawi berikut:

$$
\text { ذوض وهذاكله مالم يكن لديها عذر معتبر من إرهاق أو مانع شرع، أو غير }
$$

Selanjutnya Yusuf alQaradhawi mempertegas, jika isteri dalam keadaan sedang sakit, atau karena ada halangan syar'i maka suami harus menyadari hal itu, karena Allah SWT saja yang telah menciptakan hambahambanya, dan memberi rizki, memberikan kemudahan, dan bahkan menggugurkan kewajiban hamba-hambanya ketika sedang dalam keadaan sedang udzur, logikanya apalagi sebagai sesama hamba Allah.

\section{Penjelasan}

Suami mempunyai hak pelayanan dari seorang istri (perempuan). Sedangkan pelayanan istri terhadap suami adalah bagian dari ibadah yang akan mengantarkan kaum perempuan/istri tersebut kepada pengabdian terhadap suaminya dengan balasan kedudukan yang mulia disisi Allah SWT. Muncul pula ancaman berupa laknat dari malaikat terhadap istri yang

13 Yusuf al-Qaradhawi, Hadyul Islam fatawi Mu'asyirah, (Libanon: Darul Ma'ârif, 1988), Juz 2, hlm. 114 tidak menjalankan tugas utamanya, itu merupakan peringatan agar keberadaanya tetap dalam kemuliaan sebagai perempuan.

Selain hak di atas, berikut ini merupakan kewajiban yang

\begin{tabular}{|c|c|}
\hline $\begin{array}{c}\text { Kewajiban } \\
\text { Suami } \\
\text { Sekaligus Hak } \\
\text { Istri }\end{array}$ & $\begin{array}{c}\text { Kewajiban } \\
\text { Istri } \\
\text { Sekaligus } \\
\text { Hak Suami }\end{array}$ \\
\hline $\begin{array}{l}\text { Memberikan } \\
\text { mahar }\end{array}$ & $\begin{array}{l}\text { Taat dan } \\
\text { patuh kepada } \\
\text { suami kecuali } \\
\text { kemaksiatan }\end{array}$ \\
\hline $\begin{array}{l}\text { Nafkah dengan } \\
\text { memenuhi } \\
\text { segala keperluan } \\
\text { rumah tangga }\end{array}$ & $\begin{array}{l}\text { Tidak durhaka } \\
\text { kepada suami }\end{array}$ \\
\hline $\begin{array}{l}\text { Mengajarkan } \\
\text { istri tentang } \\
\text { ilmu agama }\end{array}$ & $\begin{array}{l}\text { Menjaga harta } \\
\text { suami dan } \\
\text { Menjaga nama } \\
\text { baik suami }\end{array}$ \\
\hline $\begin{array}{l}\text { Memberikan } \\
\text { yang mak'ruf }\end{array}$ & $\begin{array}{l}\text { Mengurus dan } \\
\text { menjaga } \\
\text { rumah } \\
\text { tangganya, } \\
\text { termasuk di } \\
\text { dalamnya } \\
\text { mengurus } \\
\text { anak-anaknya. }\end{array}$ \\
\hline $\begin{array}{l}\text { Menjaga nama } \\
\text { baik istri }\end{array}$ & $\begin{array}{l}\text { Menjaga } \\
\text { kehormatan } \\
\text { jika tidak } \\
\text { bersama } \\
\text { suami }\end{array}$ \\
\hline Bersikap adil & $\begin{array}{lr}\text { Taat dan } \\
\text { patuh kepada } \\
\text { suami kecuali } \\
\text { dalam hal } \\
\text { kemaksiatan }\end{array}$ \\
\hline DLL & DLL \\
\hline
\end{tabular}
menjadi hak istri dan kewajiban istri yang menjadi hak suami.

Berdasarkan penjelasan di atas dapat diketahui bahwa 
dalam sebuah hubungan kekeluargaan antara suami dan istri masing-masing memiliki hak dan kewajiban yang harus dipenuhi dan ditunaikan, sehingga baik suami maupun istri dapat merasakan sebuah ketenangan dengan masingmasing pasangannya. Untuk membentuk dan mewujudkan keluarga yang sakīnah mawaddah wa rahmah memerlukan peran serta tanggung jawab dari kedua belah pihak. ${ }^{14}$ Dengan mengetahui dan menunaikan segala sesuatu yang menjadi hak maupun kewajiban, diharapkan bisa mempermudah menuju keluarga bahagia tentunya dengan berdasarkan pada ajaran agama Islam dan hukum yang berlaku.

Informasi di atas menjelaskan indahnya Islam dalam pendidikan gender yang membedakan hak dan kewajiban antara laki-laki dan perempuan, dengan tujuan kesetaraan semata-mata untuk meraih kemuliaan yang setara disisi sang pencipta Allah SWT.

\section{Ganjaran Bagi Orang Tua Yang Mendidik Anak.}

\section{Sanad dan Matan}

Diriwayatkan juga dari 'Aisyah radhiyallahu 'anha, beliau berkata:

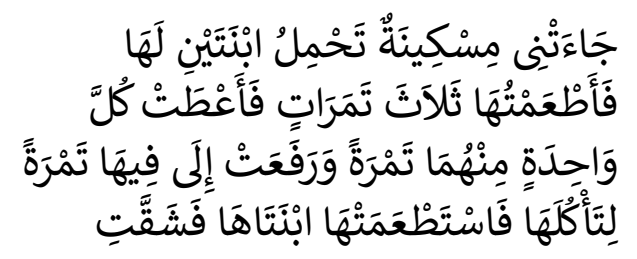

14 Nurul Afifah, Hak Suami-Istri Perspektif Hadis, Jurnal Living Hadits. Vol 2 (1). 2017. hlm. 25

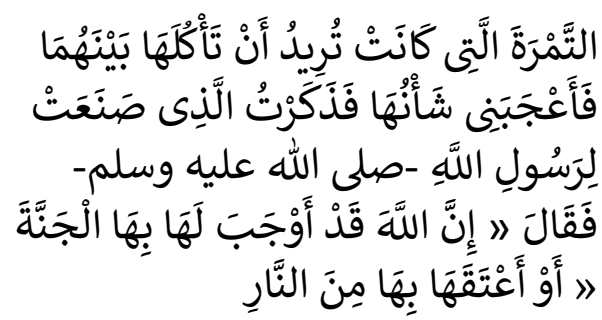

Terjema:

"Seorang wanita miskin datang kepadaku dengan membawa dua anak perempuannya, lalu aku memberinya tiga buah kurma. Kemudian dia memberi untuk anaknya masing-masing satu buah kurma, dan satu kurma hendak dia masukkan ke mulutnya untuk dimakan sendiri. Namun kedua anaknya meminta kurma tersebut. Maka si ibu pun membagi dua kurma yang semula hendak dia makan untuk diberikan kepada kedua anaknya. Peristiwa itu membuatku takjub sehingga aku ceritakan perbuatan wanita tadi kepada Rasulullah shallallahu 'alaihi wa sallam. Maka Nabi shallallahu 'alaihi wa sallam bersabda: Sesungguhnya Allah telah menetapkan baginya surga dan membebaskannya dari neraka" (H.R Muslim 2630).

\section{Pendapat Ulama}

Menurut Dr. Musthafa Sa'id Al-Khin hadits di atas memberikan faedah keutamaan untuk menjaga anak-anak kita. Dengan melaksanakan keutamaan keikhlasan dalam setiap mengerjakan sesuatu, kita akan mendapat balasan dari Allah swt seperti terhindar dari api neraka serta terhapuslah dosa-dosa. Jika dengan memberikan sepotong kurma saja dapat menghantarkan seorang ibu ke surga, apalagi jika seorang tersebut mampu 
merawat dan menjaga anak tanpa lelah dan berkeluh kesah dari pagi hingga bertemu pagi lagi. Menjadi orangtua adalah proses sepanjang hayat. Diperlukan ilmu kesabaran dan keikhlasan untuk kita agar tiba sampai gerbang rahmat-Nya. Gerbang yang akan menghantarkan kita ke pintu surga-Nya Allah Subhaanahu Wata'alaa. Aamiin

\section{Penjelasan}

Hadits di atas nampaknya terlihat ringan, tetapi karena keikhlasan tersebut maka seorang ibu memperoleh balasan surga. Dalam kondisi krisis seperti apa pun, rasa kasih sayang ibu pada anak dan tanggung jawab untuk melindungi anak maka Allah swt akan memberi anugerah yang besar kepada mereka yang bisa mewujudkan ajaran ini dengan penuh rasa pengabdian dan ikhlas.

Demikian itu seorang anak hendaknya harus berbakti kepada kedua orang tuanya, apalagi kepada ibu karena ia lah yang mengandung, melahirkan kita. Oleh karena itu kita juga harus menunjukkan rasa bakti, kasih sayang kepada orang tua sebagai wujud rasa syukur kita kepada mereka yang telah dengan susah payah (terutama ibu) mengasuh kita sewaktu kecil.

Selain hadits yang berkaitan dengan ibu. Ada hadits lain yang meceritakan bahwa seorang ayah juga akan masuk surga jika ia berhasil dalam mengurus anak. Yaitu Dari sahabat Uqbah bin Amir berkata, "Aku mendengar Rasulullah saw. bersabda,
'Barangsiapa yang mempunyai tiga anak perempuan kemudian dia bersabar, memberi makan, minum, dan pakaian dari jerih payahnya, niscaya mereka bagi ayahnya akan menjadi penghalang dari neraka." (H.R. Ibnu Majah).

Selain ibu kita juga harus hormat, berbati dan mencintai ayah kita, walaupun bukan dia yang melahirkan kita, tetapi dialah yang bersusah payah untuk mencari nafkah demi kebutuhan keluarganya.

\section{Kepemimpinan Perempuan. \\ Seorang}

\section{Sanad dan Matan.}

Dalam islam perempuan diperbolehkan untuk menjadi seorang pemimpin, namun sesuai dengan ketentuan. Salah satu hadis yang menjelaskan tentang kepemimpinan wanita yaitu:

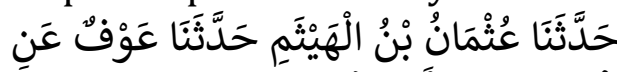

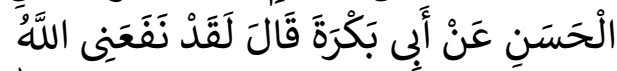

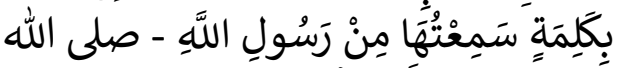

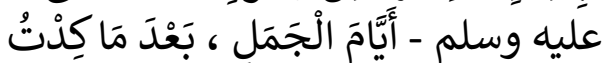

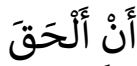

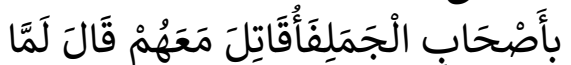

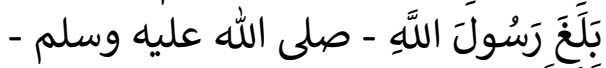

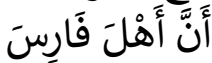

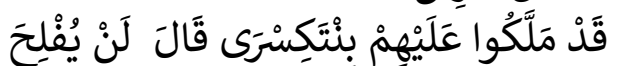

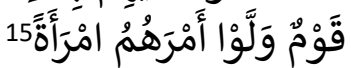

Terjema:

"Usman bin al-Haisam menceritakan kepada kami, Awf menceritakan kepada kami, dari al-Hasan, dar Abi Bakrah berkata: Sungguh Allah telah memberi kebaikan padaku tentang kalimat yang sangat penting ketika terjadi

\footnotetext{
${ }^{15} \mathrm{Al}$-Bukhari, Shahāīh Bukhāri , Juz, 2(Riyad: Dār as-Salam, 1999), hlm. 337
} 
perang jamal, dimana telah sampai (kalimat itu) kepada Nabi SAW bahwa bangsa Persia mengangkat putri Kisrah sebagai pemimpin, lalu Nabi SAW bersabda: tidak akan beruntung suatu masyarakat bila dipimpin oleh seorang pemimpin perempuan (HR. Al-Bukhari)".16

\section{Pendapat Ulama}

Secara eksplisit menurut alMaududi hal ini menunjukkan bahwa seluruh mukmin adalah khalifah Allah. Mereka bertanggung jawab kepada Allah dalam kaitannya sebagai khalifah. Seperti yang disabdakan oleh Nabi Muhammad saw: Tiap kamu adalah pemimpin dan bertanggung jawab terhadap kepemimpinannya, seorang kepala negara yang memimpin rakyat bertanggung jawab atas mereka dan seorang laki-laki adalah pemimpin rumahnya dan bertanggung jawab atas mereka (HR.Muttafaq 'alayh). ${ }^{17}$

Hadis ini dipahami oleh alMaududi bahwa masing-masing manusia mempunyai peluang dan kedudukan yang sama dan tidak ada perbedaan untuk menjadi seorang khalifah di muka bumi ini. Menurut al-Maududi dalam negara Islam, pemerintahan dibentuk secara demokratis dan diselenggarakan berdasarkan konsultasi timbal balik.

Dengan sandaran ayat di atas, al-Maududi mengatakan bahwa kekhalifahan yang dijanjikan oleh Allah bersifat

16Perpustakaan Nasional, Ensiklopedia Hadits, Sahih al-Bukhari, cet. I (Jakarta: Al-mahira, 2011), hlm. 87

${ }^{17}$ Ahmad bin Hanbâl, Musnad bin Hanbal, Jilid. II, 5 dan 54 universal dan tidak terbatas hanya pada individu atau sekelompok orang. Jika melihat pendapat al-Maududi di atas, hampir sama dengan doktrin Khawarij yang mengatakan bahwa setiap Muslim dari kalangan manapun berhak untuk menjadi kepala negara.

\section{Penjelasan}

Menurut tradisi di Persia sebelum itu, yang diangkat sebagai kepala adalah seorang laki-laki, Sedangkan tahun $9 \mathrm{H}$ itu menyalahi tradisi. Kepala negara yang terpilih seorang perempuan yakni Buwaran binti Syairawaih bin Kisrah bin Barwaiz. Dia diangkat sebagai ratu setelah terjadi pembunuhan dalam rangka suksesi kepala negara. Ayah serta saudara laki-lakinya mati terbunuh. Sebab itulah Buwaran diangkat menjadi ratu. ${ }^{18}$

Buwaran binti Syairawah merupakan seorang wanita memang tidak memiliki kualifikasi seorang pemimpin yang adil, bijaksana, visioner, dan karakteristik kepemimpinan lainnya, ia hanya ingin kepentingan ingin berkuasa (harsh: tamak). Maka oleh sebab itu Rasulullah Saw menyebutkan bahwa seorang perempuan yang tidak mempunyai kriteria dalam memimpin akan menyebabkan kehancuran, sedangkan untuk seorang perempuan yang memiliki kemampuan dibolehkan untuk menjadi pemimpin, tetapi kepemimpinannya pun harus tertentu. Tetapi jika sudah

${ }^{18}$ Erniati, Gender Dalam Perspektif Hadis Mawdhu'i, Jurnal: Musawa. Vol. 8 (1), Juni 2016, hlm. 45. 
menyangkut kepemimpinan

umat islam secara keseluran amirul mukminin tidak diperbolehkan.

Selain Buwaran yang tidak memenuhi kriteri kepemimpinan. Pada masa itu juga, derajat kaum wanita dalam masyarakat berada di bawah derajat kaum laki-laki. Wanita sama sekali tidak dipercaya untuk mengurus kepentingan masyarakat umum, terlebih lagi dalam negara. Bagaimana mungkin akan sukses, kalau orang yang memimpin itu adalah mahkluk yang sama sekali tidak dihargai oleh masyarakat yang dipimpinnya. Karena salah satu syarat menjadi pemimpin haruslah berwibawa, sedangkan pada saat itu wanita tidaklah berwibawa. ${ }^{19}$

Perlu digaris bawahi bahwa hadis di atas tidak bersifat umum, hadis ini ditujukan kepada masyarakat Persia pada masa itu, bukan terhadap semua masyarakat dan dalam semua urusan. ${ }^{20}$ Kenyataannya sudah banyak perempuan menjadi pemimpin, berarti perempuan telah terbukti bahwa ia mampu menjadi pemimpin. Berarti kata قَوَّمُونَ dalam ayat tersebut menggambarkan bahwa hanya laki-laki tertentu dan perempuan tertentu yang mempunyai kekuatan (kelebihan tersendiri) yang dapat menjadi pemimpin. ${ }^{21}$

Tidak ada batasan perempuan untuk berperan, tetapi harus memperhatikan ketentunnya. Contohnya ketika Umar memilih Ummu Syifa putri

\footnotetext{
${ }^{19}$ Ibid,. hlm: 46.

${ }^{20}$ Quraish, Shihab. Wawasan Al-Qur'an, Cet. XII, (Bandung: Mizan, 2001), hlm. 314

${ }^{21}$ Supardin,. Ibid,hlm.57
}

dari Abdullah Al-Makhzumiyah sebagai hakim dalam penentukan harga, berat, dan ukuran yang digunakan di pasar. Contoh lain dalam kepemimpinan di bidang pengadilan. Imam Abu Hanifah mengatakan bahwa wanita tidak dilarang untuk menempati kedudukan di sistem pengadilan dalam masalah yang sesuai dengan bidang kemampuan kasus tertentu dan situasi tertentu.Namun kepemimpinan ini tidak bolehmenjadikannya berlaku sewenang-wenang. ${ }^{22}$

Dalam situasi tertentu wanita bisa saja menjadi seorang pemimpin apabila mempunyai kemampuan yang memadai dan bukan pemimpin umat Islam secara keseluruhan seperti khalifah. Bisa menjadi hakim, manejer perusahaan, dan posisi lainnya yang tidak terkait dengan kepemimpinan agama dalam Islam. ${ }^{23}$

Walaupun tidak ada larangan yang kuat untuk perempuan memegang kepemimpinan, apabila mereka benar mampu maka mereka boleh memimpin tetapi tidak boleh melalaikan tanggungjawab utamanya terhadap keluarga, jika ditakutkan dapat melalaikan tanggungjawabnya maka tidak boleh. Oleh sebab itu wanita karir harus memperhatikan seluruh tanggung jawab serta tugasnya di rumah sebagai istri dan ibu, demi kesejahteraan keluarganya.

\section{KESIMPULAN}

\footnotetext{
${ }^{22}$ Abuddin Nata, Metodologi Studi Islam, (Jakarta: Rajawali Pers, 2014), hlm. 142.

23 Meirison, Sejarah Kepemimpinan Wanita di Timur Tengah Dalam Tinjauan Hukum Islam (Analisa Terhadap Syajar al Durr), Jurnal: Kafa'ah, Vol. 9 (1), 2019, hlm.61
} 
Hasil kajian ini menjelaskan bahwa gender itu bukanlah sesuatu yang menyebabkan perbedaan antara lakilaki dan perempuan, namun gender merupakan sebuah tanggungjawab masing-masing dari hasil kontruksi sosial budaya sekitar. Hadis-hadis yang telah dijelaskan merupakan sebagain dari hadis yang mencerikan tentang gender.

Dalam memahami makna yang terkandung di dalam hadis, sangat diperlukan pengetahuan yang mendalam dan detail terkait dengar hadis tersebut. Karena jika tidak dilakukan kajian secara mendalam dan detail maka akan timbul pemahaman yang menyimpang.

\section{REFERENSI}

Adriana, Iswah. Kurikulum Berbasis Gender. Jurnal Tadris. Vol.4 (1), 2009.

Al-Bukhari. Shahaīh Bukhāri , Juz, 2. Riyad: Dār as-Salam, 1999.

Al-Bagwiy, Muhammad Al-Husayn. Syarah al-Sunnah. Juz. V. Beirut: Dar al-Kutub al-Ilmiyah, 1992.

Al-Qaradhawi, Yusuf. Hadyul Islam fatawi Mu'asyirah. Libanon: Darul Ma'ârif. Juz 2, 1988.

Afifah, Nurul. Hak Suami-Istri Perspektif Hadis, Jurnal Living Hadits. Vol 2, No. 1, 2017.

Andika, Mayola, Reinterpretasi Ayat Gender Dalam Memahami Relasi Laki-Laki dan Perempuan, Jurnal: Musawa. Vol. 17 (2), 2018.

Darwis, Amri. Metode Penelitian Pendidikan Agama Islam Pengembangkan Ilmu Beroaradigma Islami.

Pekanbaru:Suska Press, 2021.

Erniati. Gender Dalam Perspektif Hadis Mawdhu'i. Jurnal: Musawa. Vol. $8 \quad$ No.12016.
Faqih, Mansour.Analisis Gender dan Transformasi Sosial. Yogyakarta: Pustaka Pelajar, 2006.

Hanbal, Ahmad bin dan Musnad bin Hanbal, Jilid. II.

Kholifah, Nur Dan Dede Mercy Rolando, Stereotipe Perempuan Dakwah Ustadz Abdul Somad: Perspektif Representasi, AlIdza'ah: Jurnal Dakwah Dan Komunikasi. Vol. 2 (2), 2020

Meirison, Sejarah Kepemimpinan Wanita di Timur Tengah Dalam Tinjauan Hukum Islam (Analisa Terhadap Syajar al Durr),Jurnal: Kafa'ah. Vol. 9 (1), 2019.

Nata, Abuddin. Metodologi Studi Islam. Jakarta: Rajawali Pers, 2014.

Narwoko, Dwi dan Bagong Yuryanto, Sosiologi Teks Pengantar dan Terapan. Jakarta: Kencana Prenada Media Group, 2004.

Perpustakaan Nasional.Ensiklopedia Hadits, Sahih al-Bukhari, cet. I. Jakarta: Al-Mahira, 2011.

Ridwan, Kekerasan Berbasis Gender. Yogyakarta: Fajar Pustaka, 2006.

Supardin, Kajian Gender Perspektif Hadis Nabi. Jurnal: Al-Fikr. Vol.12 (1), 2013.

Shihab, Quraish. Wawasan Al-Qur'an, Cet. XII. Bandung: Mizan, 2001.

Sukmadinata, Nana Syaodih. Metode Penelitian Pendidikan. Bandung: Remaja Rosdakarya, 2009.

Umar, Nassaruddin.Argumen Kesetaraan Gender. Jakarta: Dian Rakyat, 2010.Zahid. PDF Sohih Bukhari. Da'wahrights, 2010.

Wilda, Yassirli Amria, Konsep Kesetaraan Gender Husein Muhammad Dan Relevansinya Terhadap Tujuan Pendidikan Agama Islam. Skripsi, Yogyakarta: UIN Sunan Kalijaga, 2018. 
Gender: Kedudukan Ikhwan dan Akhwat Perspektif Hadis Shahih | Wisudatul Ummi Tanjung 